\title{
Krzysztof Hołubowicz
}

Uniwersytet Ekonomiczny we Wrocławiu

\section{KORELACJA INDEKSÓW CEN AKCJI NA GLOBALNYCH RYNKACH FINANSOWYCH}

\begin{abstract}
Streszczenie: Artykuł ma na celu ukazanie powiązań na światowych rynkach finansowych. Celem jest odpowiedź na następujące pytania badawcze:

1. Jak silne są związki poszczególnych parkietów światowych?

2. Czy w okresie bessy lub hossy powiązania są silniejsze lub słabsze?

3. Z jakimi rynkami najbardziej powiązany jest polski indeks giełdowy WIG 20 ?

Autor, badając wzajemne zależności, uzyskał informacje o powiązaniach korelacyjnych, które występują pomiędzy giełdami na całym świecie. Główny wniosek, który wysnuwa się po analizie danych, to pozytywne zależności pomiędzy poszczególnymi parkietami na świecie. Natomiast biorąc pod uwagę siłę zależności, nie można jednoznacznie stwierdzić, iż jest ona znacząca w długim terminie czasowym. Natomiast można wyraźnie zauważyć na podstawie otrzymanych wyników silne powiązania pomiędzy rynkami w krótszych okresach. Stanowić to może przyczynek do dalszych prac nad zbadaniem czynników makroekonomicznych, które mają wpływ na wahania notowań poszczególnych giełd światowych.
\end{abstract}

Słowa kluczowe: korelacja, rynki finansowe, kryzys finansowy.

DOI: $10.15611 /$ nof.2014.2.04

\section{Wstęp}

Powiązania na światowych rynkach finansowych stanowią nieodłączny element ich funkcjonowania. Nowoczesne źródła przekazu informacji, wysyłanie, jak również dostarczanie wiadomości inwestorom w czasie rzeczywistym oraz handel on-line 24 godziny na dobę sprawiają, iż ten sam kierunek notowań jest widoczny na każdym parkiecie giełdowym, co przekłada się na podobne zachowania osób zaangażowanych na giełdach światowych. Jednak relatywna siła poszczególnych parkietów oraz stopień wzrostu lub spadku rynku jest różny w zależności od kraju. Dlatego też zbadanie wzajemnych zależności stanowi podstawę do odpowiedzi na pytania:

1. Jak silne są związki poszczególnych parkietów światowych?

2. Czy w okresie bessy lub hossy powiązania są silniejsze lub słabsze?

3. Z jakimi rynkami najbardziej powiązany jest polski indeks giełdowy WIG20?

Ponadto w ostatnim czasie, począwszy od 1999 r., miało miejsce wiele wydarzeń gospodarczych, które w znaczny sposób oddziaływały na wzmożoną integrację pomiędzy różnymi rynkami. Do tych zdarzeń można zaliczyć m.in.: 
- wprowadzenie w 1999 r. unii monetarnej, która zacieśniła relacje gospodarcze pomiędzy jej członkami [Syllignakis 2006],

- większenie płynności oraz szerokości rynku dzięki zmniejszonym kosztom transakcyjnym [Danthine, Giavazzi, Thadden 2000],

- pęknięcie bańki internetowej oraz kryzys finansowy zapoczątkowany upadkiem Lehman Brothers,

- przyjęcie polityki monetarnej polegającej głównie na dodruku pieniądza (tzw. quantitative easing).

Ciekawą pracą w tym aspekcie jest również dzieło Hubera oraz Riegera [2004], którzy przeprowadzili badania 11 krajów unii monetarnej w latach 1997-2003, uzyskując zaskakujący rezultat, mówiący o tym, iż czynniki o znaczeniu makroekonomicznym mają mniejsze znaczenie dla akcji niż czynniki branżowe. Na tej podstawie można bowiem założyć, przy uwzględnieniu występujących korelacji, iż czynnik polityczny oraz prowadzona polityka gospodarcza jest nieistotna przy wyborze inwestycji. Niemniej jednak badanie objęło państwa o ugruntowanej pozycji i na podobnym etapie rozwoju, co mogło niejako zaburzyć interpretację uzyskanych wyników.

Celem artykułu była próba odpowiedzi na postawione powyżej pytania oraz wysunięcie wniosku, czy dywersyfikacja pomiędzy rynkami istotnie wpływa na obniżenie poziomu ryzyka. Zbadanie korelacji przyczynić się może do wyboru rynków do inwestycji, mając na uwadze wzajemne powiązania pomiędzy rynkami finansowymi poszczególnych państw.

\section{Badanie największych rynków giełdowych oraz ich powiązania z polską giełdą papierów wartościowych}

Analiza wzajemnych zależności w pierwszej kolejności polegała na wyznaczeniu rynków, które mają największe znaczenie w danym regionie. W tym przypadku do badań wybrano następujące indeksy giełdowe:

- S\&P 500 - Stany Zjednoczone,

- DAX - Niemcy,

- FTSE - Wielka Brytania,

- NIKKEI - Japonia,

- WIG - Polska,

- MERVAL - Argentyna,

- BOVESPA - Brazylia.

Skład indeksu obejmuje wszystkie najważniejsze rynki z uwzględnieniem naszego rodzimego rynku giełdowego, począwszy od Ameryki Północnej (S\&P), przez Amerykę Południową (Bovespa oraz Merval), Europę (Dax, FTSE, WIG), aż po rynek azjatycki reprezentowany w badaniu przez Nikkei.

W okresach względnego spokoju liczba publikacji na temat powiązań na rynkach finansowych wyraźnie spada, natomiast w czasach turbulencji autorzy chętnie 
opisują wzajemne zależności, które bardzo często nabierają efektu domina, zarażając kolejne rynki finansowe. Okres badania objął lata 1999-2011, natomiast końcówka XX wieku, kiedy na rynkach panowała hossa, była poprzedzona kryzysem z roku 1997, którego epicentrum znalazło się w regionie Azji, jednak poprzez silne powiązania gospodarcze kolejne państwa w centralnej oraz wschodniej Europie zostały zainfekowane kryzysem. Na ten temat Forbes i Rigobon w 2002 r. stworzyli pracę, w której wykazali, że w wyniku kryzysu azjatyckiego oraz bessy panującej na rynkach amerykańskich nie istniał jeszcze efekt zarażania pomiędzy rynkami, lecz jedynie wzajemna zależność. Należy przy tym zauważyć, iż istnieje cienka granica pomiędzy wzajemną zależnością oraz efektem zarażania, który jest zdefiniowany jako wyraźna zmiana pomiędzy powiązaniami na rynkach finansowych w czasach turbulencji [Forbes, Rigobon 2002, s. 2223-2261]. Ponadto w pracy tej wykazano, iż w czasach kryzysów finansowych istnieje zauważalna tendencja do turbulencji, które są bardzo intensywne, lecz relatywnie krótkie. Według autorów tej pracy, ceny akcji po wstrząsie wracają do poziomów z czasów prosperity, z reguły w ciągu trzech lat od dna bessy. $Z$ kolei w okresach spokoju gospodarczego zauważalna jest tendencja do szybkiego wzrostu na rynkach rozwijających się.

Bardzo ciekawym badaniem może pochwalić się Horobet, która zwraca uwagę, iż w krótkich okresach występują silniejsze zależności pomiędzy parkietami giełdowymi, natomiast zależność ta ulega znacznemu osłabieniu w dłuższych okresach. Wskazuje przy tym na czynniki, które mają decydujący wpływ na kryzys oraz wzajemne przenikanie się rynków. Należy do nich bardzo łatwy dostęp do rynków globalnych oraz niedostateczna ocena ryzyka, które niesie za sobą inwestowanie w akcje [Horobet 2010, s. 195-200]. Wydaje się, że zastosowanie ma tutaj psychologia thumu, która przy niedostatecznej wiedzy osób inwestujących na rynkach finansowych powoduje kopiowanie zachowań innych inwestorów.

Mink oraz Mierau z kolei przeprowadzili badania, z których wynikło, iż podczas okresów spokoju, zdefiniowanych jako brak nadzwyczajnych zdarzeń, bankructw oraz masowych problemów państw z długiem, korelacje pomiędzy rynkami finansowymi są słabe. Natomiast wyraźnie wzrastają, jeśli inwestorzy mają do czynienia ze zjawiskiem nagłego spadku cen [Mink, Mierau 2009]. Także w tym wypadku można mówić o stopniowym zarażaniu kryzysem kolejnych państw, co ma odzwierciedlenie w funkcjonowaniu globalnego rynku finansowego.

Ostatnie z przytoczonych badań na temat wzajemnych powiązań oraz korelacji na rynkach opracowali Markwat, Kole oraz van Dijk, którzy zauważyli, że w każdym przypadku w czasie kryzysu ma zastosowanie efekt domina i nie ma żadnego kraju, którego działanie nie byłoby uzależnione od wydarzeń makroekonomicznych w innych państwach [Markwat, Kole, van Dijk 2009, s. 1996-2012]. W związku $\mathrm{z}$ tym lokalne problemy jednego państwa lub całej grupy państw w danym regionie w czasie kryzysu zwiększają powiązania na rynkach międzynarodowych, powodując spadki cen akcji na wszystkich parkietach globalnych rynków finansowych. Trzeba również zwrócić uwagę na fakt, iż silniejsze powiązania poszczególnych par- 
kietów giełdowych obniżają możliwość zdywersyfikowania ryzyka, a więc w ostatecznym rozrachunku w czasach niepewności rynkowej nie działa zasada obniżania ryzyka poprzez inwestowanie na różnych rynkach.

Ogólnie można więc stwierdzić, na podstawie literatury przedmiotu, iż podczas bessy powiązania pomiędzy rynkami są silniejsze. Z kolei w czasie stabilizacji oraz wzrostów korelacji pomiędzy rynkami - są znacznie niższe. Ostatni kryzys finansowy, określany terminem subprime, szczególnie zainfekował kraje z bardzo rozwiniętym sektorem finansowym (takie jak Belgia, Francja, Niemcy, Irlandia, Islandia, Holandia, Szwajcaria, Wielka Brytania oraz USA). Mink oraz Mierau [2009] zauważyli, iż rynki akcji w tych krajach zanotowały spadki niemal równocześnie, co jest znakiem potwierdzającym wzajemne powiązania rynków finansowych.

Niniejszy artykuł jest próbą odpowiedzi na pytanie, jaka faktycznie występuje korelacja pomiędzy czołowymi rynkami finansowymi świata z uwzględnieniem polskiego rynku papierów wartościowych w długim okresie, jak również w podziale na lata hossy i bessy w latach 1999-2011.

\subsection{Korelacja na globalnych rynkach finansowych z uwzględnieniem powiązań polskiego rynku finansowego}

\section{Metodologia}

W badanym okresie, tzn. w latach 1999-2011, autor zebrał dane dotyczące sześciu rynków światowych oraz polskiego rynku giełdowego. Metodę pracy stanowi głównie analiza opisowa oparta na materiałach dostępnych w publikacjach zwartych i periodykach.

Do analizy wzięte zostały jedynie te dni sesyjne, w których sesje odbywały się na wszystkich parkietach. Miało to na celu wyeliminowanie przypadków, kiedy jeden z parkietów funkcjonował bez innych, nie mogło bowiem dojść wówczas do wzajemnych zależności. W ciągu trzynastu lat sesyjnych łącznie było 2786 dni, w których sesja giełdowa odbywała się na wszystkich parkietach. Daje to przeciętnie 214,3 dnia sesyjnego w ciągu roku. Wynika z tego, że w ciągu roku przez $82 \%$ czasu pracy liczonego jako 52 tygodnie z pięciodniowym tygodniem pracy funkcjonują wszystkie parkiety światowe.

Siła wzajemnej zależności zbadana korelacją liniową została przedstawiona w tab. 1.

Dane wyjściowe $\mathrm{z}$ tab. 1 dają nam do zrozumienia, iż w długim okresie zależności pomiędzy ruchami indeksów istnieją, jednak w większości przypadków ich siła jest relatywnie słaba. Polski parkiet (WIG) notował ścisłe zależności z rynkami określanymi również jako tzw. emerging markets. Współczynnik korelacji wyniósł bowiem aż $0,87 \mathrm{w}$ przypadku parkietów południowoamerykańskich (odpowiednio 0,87 dla powiązania z brazylijskim rynkiem oraz 0,877 dla rynku argentyńskiego).

Zaskakujący może z kolei być fakt, iż zależność pomiędzy polskim oraz amerykańskim rynkiem finansowym jest relatywnie słaba w długim przedziale czasowym. 
Tabela 1. Korelacja pomiędzy wybranymi rynkami finansowymi w latach 1999-2011

\begin{tabular}{|l|c|c|c|c|c|c|c|}
\hline & BOVESPA & MERVAL & NIKKEI & DAX & FTSE & S\&P & WIG \\
\hline BOVESPA & 1,000 & 0,923 & $-0,142$ & 0,545 & 0,229 & 0,188 & 0,870 \\
\hline MERVAL & & 1,000 & $-0,136$ & 0,490 & 0,239 & 0,247 & 0,877 \\
\hline NIKKEI & & & 1,000 & 0,574 & 0,798 & 0,822 & 0,178 \\
\hline DAX & & & & 1,000 & 0,872 & 0,818 & 0,630 \\
\hline FTSE & & & & & 1,000 & 0,935 & 0,408 \\
\hline S\&P & & & & & & 1,000 & 0,449 \\
\hline WIG & & & & & & & 1,000 \\
\hline
\end{tabular}

Źródło: opracowanie własne na podstawie danych dostępnych na www.bossa.pl.

Niejednokrotnie można spotkać się z twierdzeniami, iż uzależnieni jesteśmy od notowań na rynku amerykańskim, lecz niekoniecznie znajduje to potwierdzenie w danych statystycznych.

Widać również wyraźną tendencję, że parkiety rozwinięte są ze sobą silniej powiązane niż młode rynki. Ciekawy jest również fakt negatywnej wręcz korelacji pomiędzy indeksem Nikkei z indeksami BOVESOA oraz MERVAL. W celu dokładniejszej analizy zbadane zostały ruchy cen w krótszych przedziałach czasowych, które mogą dać odpowiedź na pytanie, czy warto sugerować się notowaniami oraz trendami na innych rynkach.

\subsection{Korelacje pomiędzy rynkami globalnymi w okresach hossy/bessy}

Przedziały czasowe hossy oraz bessy zostały zaczerpnięte z funkcjonowania najbardziej rozwiniętego rynku o największej kapitalizacji, czyli S\&P, który uznawany jest za rynek bazowy do podejmowania decyzji inwestycyjnych.

Wykres na rys. 1 pozwolił na wyodrębnienie pięciu okresów:

- I kw. 1999 - III kw. 2000 - koniec hossy lat dziewięćdziesiątych,

- III kw. 2000 - I kw. 2003 - bessa spowodowana pęknięciem bańki tzw. dotcomów,

- I kw. 2003 - IV kw. 2007 - hossa na rynkach finansowych,

- IV kw. 2007 - I kw. 2009 - kryzys finansowy wywołany nadmiernym zadłużeniem,

- I kw. 2009 - IV kw. 2011 - odbudowa po uzyskaniu dna bessy oraz hossa największych spółek amerykańskich.

W celu zbadania korelacji zostały także wybrane tzw. lokalne minima oraz maksima stanowiące punkty zwrotne $\mathrm{w}$ danym przedziale czasowym. Poniższe wyniki pokazują zależności pomiędzy rynkami, gdy rynek bazowy znajduje się w jednoznacznie określonym trendzie. 


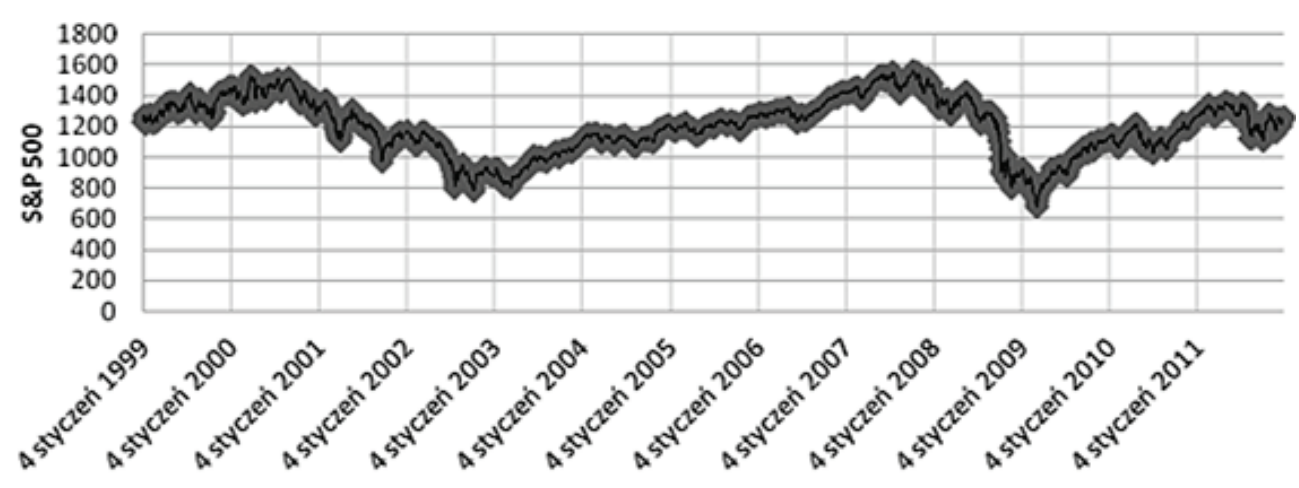

Rys. 1. Wykres amerykańskiego rynku S\&P w latach 1999-2011

Źródło: opracowanie własne na podstawie danych giełdowych dostępnych na www.bossa.pl.

\section{I kw. 1999 - III kw. 2000 - koniec hossy lat dziewięćdziesiątych}

Tabela 2. Korelacja pomiędzy wybranymi rynkami finansowymi w okresie I kw. 1999 r. - III kw. 2000 r.

\begin{tabular}{|l|c|c|c|c|c|c|c|}
\hline & BOVESPA & MERVAL & NIKKEI & DAX & FTSE & S\&P & WIG \\
\hline BOVESPA & 1,000 & 0,676 & 0,656 & 0,936 & 0,553 & 0,870 & 0,884 \\
\hline MERVAL & & 1,000 & 0,842 & 0,558 & 0,444 & 0,499 & 0,621 \\
\hline NIKKEI & & & 1,000 & 0,563 & 0,451 & 0,564 & 0,674 \\
\hline DAX & & & & 1,000 & 0,433 & 0,839 & 0,928 \\
\hline FTSE & & & & & 1,000 & 0,701 & 0,415 \\
\hline S\&P & & & & & & 1,000 & 0,784 \\
\hline WIG & & & & & & & 1,000 \\
\hline
\end{tabular}

Źródło: opracowanie własne na podstawie danych dostępnych na www.bossa.pl.

Na uwagę zasługuje fakt, iż nie zanotowano żadnych ujemnych korelacji, czyli wszystkie rynki notowały w tym czasie wzrosty. NIKKEI oraz BOVESPA i MERVAL, które w długim okresie czasu zanotowały ujemny współczynnik korelacji, w końcówce lat dziewięćdziesiątych miały dość silne wzajemne powiązanie wynoszące odpowiednio 0,656 oraz 0,842 . Polski rynek z kolei w tym okresie zachowywał się podobnie jak niemiecki DAX, z którym powiązanie wyniosło 0,928 . Ze względu na bliskość geograficzną oraz dużą różnicę w rozwoju rynku giełdowego nie powinien dziwić fakt, iż polscy inwestorzy bacznie obserwowali poczynania na rynku we Frankfurcie.

\section{III kw. 2000 - I kw. 2003 - bessa spowodowana pęknięciem bańki tzw. dotcomów}

W okresie bessy faktycznie można zauważyć bardzo silne powiązania indeksu S\&P $\mathrm{z}$ innymi rynkami finansowymi z wyjątkiem argentyńskiego indeksu MERVAL. Ogólnie MERVAL zachowywał się bardzo niezależnie, notując ujemny współczyn- 
Tabela 3. Korelacja pomiędzy wybranymi rynkami finansowymi w okresie III kw. 2000 - I kw. 2003 r.

\begin{tabular}{|l|c|c|c|c|c|c|c|}
\hline & BOVESPA & MERVAL & NIKKEI & DAX & FTSE & S\&P & WIG \\
\hline BOVESPA & 1,000 & 0,177 & 0,849 & 0,914 & 0,904 & 0,917 & 0,728 \\
\hline MERVAL & & 1,000 & 0,062 & $-0,071$ & $-0,079$ & $-0,011$ & 0,426 \\
\hline NIKKEI & & & 1,000 & 0,940 & 0,933 & 0,935 & 0,694 \\
\hline DAX & & & & 1,000 & 0,991 & 0,978 & 0,646 \\
\hline FTSE & & & & & 1,000 & 0,982 & 0,660 \\
\hline S\&P & & & & & & 1,000 & 0,691 \\
\hline WIG & & & & & & & 1,000 \\
\hline
\end{tabular}

Źródło: opracowanie własne na podstawie danych dostępnych na www.bossa.pl.

nik korelacji nie tylko z rynkiem amerykańskim, lecz również niemieckim oraz brytyjskim. Oprócz więc niezależnego zachowania rynku argentyńskiego pozostałe giełdy notowały bardzo zbliżony kierunek notowań.

\section{I kw. 2003 - IV kw. 2007 - hossa na rynkach finansowych}

Tabela 4. Korelacja pomiędzy wybranymi rynkami finansowymi w okresie I kw. 2003 - IV kw. 2007 r.

\begin{tabular}{|l|c|c|c|c|c|c|c|}
\hline & BOVESPA & MERVAL & NIKKEI & DAX & FTSE & S\&P & WIG \\
\hline BOVESPA & 1,000 & 0,960 & 0,941 & 0,990 & 0,965 & 0,973 & 0,984 \\
\hline MERVAL & & 1,000 & 0,931 & 0,960 & 0,974 & 0,972 & 0,942 \\
\hline NIKKEI & & & 1,000 & 0,952 & 0,969 & 0,931 & 0,942 \\
\hline DAX & & & & 1,000 & 0,977 & 0,979 & 0,991 \\
\hline FTSE & & & & & 1,000 & 0,966 & 0,963 \\
\hline S\&P & & & & & & 1,000 & 0,964 \\
\hline WIG & & & & & & & 1,000 \\
\hline
\end{tabular}

Źródło: opracowanie własne na podstawie danych dostępnych na www.bossa.pl.

Najdłuższy okres w badaniu przypada na stabilizację oraz wysoki wzrost wartości indeksów w latach 2003-2007. Widać wyraźnie niewiarygodną wręcz zgodność kierunku notowań, ponieważ w żadnym ze zbadanych przepadków nie zanotowano korelacji niższej niż 0,9 , co jednoznacznie potwierdza hossę na wszystkich światowych rynkach akcji.

W tym okresie wszystkie parkiety notowały historyczne maksima, a kraje rozwijające się zyskiwały dodatkowo na inwestycjach kapitału zagranicznego, który często opuszczał rozwinięte rynki w celu poszukiwania wysokich stóp zwrotu. 
IV kw. 2007 - I kw. 2009 - kryzys finansowy wywołany nadmiernym zadłużeniem

Tabela 5. Korelacja pomiędzy wybranymi rynkami finansowymi w okresie IV kw. 2007 - I kw. 2009 r.

\begin{tabular}{|l|c|c|c|c|c|c|c|}
\hline & BOVESPA & MERVAL & NIKKEI & DAX & FTSE & S\&P & WIG \\
\hline BOVESPA & 1,000 & 0,970 & 0,910 & 0,895 & 0,931 & 0,930 & 0,854 \\
\hline MERVAL & & 1,000 & 0,958 & 0,951 & 0,967 & 0,972 & 0,935 \\
\hline NIKKEI & & & 1,000 & 0,983 & 0,975 & 0,982 & 0,965 \\
\hline DAX & & & & 1,000 & 0,987 & 0,985 & 0,975 \\
\hline FTSE & & & & & 1,000 & 0,986 & 0,969 \\
\hline S\&P & & & & & & 1,000 & 0,962 \\
\hline WIG & & & & & & & 1,000 \\
\hline
\end{tabular}

Źródło: opracowanie własne na podstawie danych dostępnych na www.bossa.pl.

Podobna synchronizacja jak w przypadku hossy widoczna była również w latach 2007-2009, czyli w czasie, kiedy wybuchł kryzys finansowy, a światowe instytucje finansowe traciły wiarygodność. W połączeniu z problemami państw doszło do wyprzedaży na rynkach akcji. Żaden parkiet nie potrafił oprzeć się przecenie, czego potwierdzenie znaleźć można w wynikach korelacji pomiędzy poszczególnymi parkietami. Wartości zanotowane w tym okresie były bardzo podobne do wcześniejszego. Jedynie BOVESPA osiągnęła współczynnik korelacji mniejszy niż 0,9 w przypadku korelacji z niemieckim DAX-em oraz polskim WIG-iem.

\section{I kw. 2009 - IV kw. 2011 - odbudowa po uzyskaniu dna bessy oraz hossa największych spólek amerykańskich}

Tabela 6. Korelacja pomiędzy wybranymi rynkami finansowymi w okresie I kw. 2009 - IV kw. 2011 r.

\begin{tabular}{|l|c|c|c|c|c|c|c|}
\hline & BOVESPA & MERVAL & NIKKEI & DAX & FTSE & S\&P & WIG \\
\hline BOVESPA & 1,000 & 0,610 & 0,613 & 0,707 & 0,798 & 0,627 & 0,788 \\
\hline MERVAL & & 1,000 & 0,222 & 0,935 & 0,921 & 0,948 & 0,926 \\
\hline NIKKEI & & & 1,000 & 0,383 & 0,391 & 0,255 & 0,379 \\
\hline DAX & & & & 1,000 & 0,935 & 0,919 & 0,967 \\
\hline FTSE & & & & & 1,000 & 0,958 & 0,959 \\
\hline S\&P & & & & & & 1,000 & 0,919 \\
\hline WIG & & & & & & & 1,000 \\
\hline
\end{tabular}

Źródło: opracowanie własne na podstawie danych dostępnych na www.bossa.pl.

W chwili obecnej ciężko jest jednoznacznie odpowiedzieć, czy wszystkie kraje są już w fazie stabilnego wzrostu. Wydaje się, że wciąż jeszcze wiele państw nie poprawiło swojej pozycji do takiego stopnia, żeby kapitał z bogatych, rozwiniętych 
krajów mógł ponownie wesprzeć rynki rozwijające się. Ponownie pojawia się sytuacja, w której silne, rozwinięte spółki amerykańskie, brytyjskie lub niemieckie zyskują na wartości, lecz niekoniecznie taki trend jest zauważalny w Japonii lub Brazylii. Widać też, że właśnie kierunek japońskich cen akcji najbardziej odbiega od pozostałych. Natomiast wartości powyżej 0,9 świadczą o tym, że tropem amerykańskiego rynku bazowego podąża Wielka Brytania oraz Niemcy.

\subsection{Powiązania kierunku cen akcji polskiego rynku finansowego z największymi rynkami giełdowymi}

Na podstawie całego okresu badania (1999-2011) można stwierdzić, że polski rynek akcji wciąż najbardziej zsynchronizowany jest z krajami rozwijającymi się. Niemniej jednak trzeba zwrócić uwagę na otoczenie makroekonomiczne, które miało bardzo duży wpływ w badanym okresie. Wejście do Unii Europejskiej, wysokie poziomy wzrostu PKB w latach 2003-2008 oraz coraz lepsze postrzeganie na arenie międzynarodowej wyraźnie zbliżyło kierunek notowań polskich akcji do rynków zachodnich. Widać to wyraźnie zwłaszcza od 2003 r., kiedy to WIG miał współczynnik korelacji ponad 0,9 względem wszystkich rozwiniętych gospodarek. Tak samo jest też w chwili obecnej, gdy podobne wartości wskaźnika korelacji świadczą o podobnych warunkach do inwestowania jak w przypadku rynku amerykańskiego. Należy jednak zwrócić uwagę, iż badanie to objęło korelacje na rynkach finansowych bez uwzględnienia zmian instytucjonalnych, umożliwiających łatwiejsze inwestowanie oraz pokazujących zwiększoną wiarygodność na arenie międzynarodowej.

\section{Wnioski}

Autor, badając wzajemne zależności, uzyskał informacje o powiązaniach korelacyjnych, które występują pomiędzy giełdami na całym świecie. Przede wszystkim pozytywnie należy odpowiedzieć na pytanie, czy w tym samym dniu roboczym występują zależności pomiędzy poszczególnymi parkietami na świecie. Natomiast biorąc pod uwagę siłę zależności, nie można jednoznacznie stwierdzić, iż jest ona znacząca pomiędzy wszystkimi rynkami na świecie. Należy zwrócić uwagę na przedziały czasowe korelacji. Uzyskane wyniki, mieszczące się w zakresie od $-0,14$ do nawet 0,99 , pokazują, że w zależności od fazy rynku oraz stopnia rozwoju całej gospodarki korelacja może być ujemna, czyli nie ma wtedy żadnego powiązania na rynkach, lub też zmiany cen głównych indeksów mogą podążać w niemal identyczny sposób. Takim przykładem jest indeks WIG i DAX w okresie 2003-2007, gdy korelacja wyniosła 0,991 .

Odpowiadając na pierwsze pytanie, które było celem artykułu i dotyczyło siły wzajemnych zależności na rynkach globalnych, widzimy wyraźnie, iż w krótszych okresach, uwzględniających pojedynczy ruch cen, związki pomiędzy poszczególny- 
mi rynkami finansowymi są silne, czego potwierdzeniem są wysokie wartości wskaźnika korelacji. Z kolei analizując cały okres badania, zauważamy wyraźne osłabienie wzajemnych zależności. Może to wynikać z różnych faz cyklu koniunkturalnego w danej gospodarce oraz jej wewnętrznych czynników makroekonomicznych, do których zaliczyć można m.in.: zmiany w prowadzonej polityce gospodarczej, wprowadzanie nowych ulg i zachęt inwestycyjnych, nastawienie gospodarki na innowacyjność. Efektem tego może być przyspieszenie wzrostu PKB oraz - co za tym idzie - podążanie zgodnie z ruchem cen innych indeksów w okresie hossy oraz mniejsze spadki w czasie bessy i nieco odmienny charakter cyklu niż w gospodarce bazowej, którą jest rynek amerykański.

Z kolei ważne z punktu widzenia polskich inwestorów są kwestie powiązań z innymi rynkami finansowymi. I tak jak można zauważyć, najsilniejsza korelacja, biorąc pod uwagę okres 1999-2011, występuje z rynkiem argentyńskim oraz brazylijskim, lecz gdybyśmy wyeliminowali przedział czasowy III kw. 2000 - I kw. 2003, polski rynek byłby najbardziej skorelowany z rynkiem niemieckim. W pozostałych okresach bowiem współczynnik korelacji wynosi za każdym razem powyżej 0,9 , co jednoznacznie wskazuje na ten sam kierunek oraz zakres wahań cen na rynkach akcji.

Badając wzajemne zależności na parkietach światowych, można zauważyć wyraźną globalizację działania parkietów giełdowych. Rozwój technologii oraz wzrost możliwości inwestycji sprowadza się do kopiowania ruchów cen akcji z rynków bazowych, najbardziej rozwiniętych pod względem produktów finansowych, wysokości obrotów oraz kapitalizacji spółek.

Konkludując, należy poprzeć tezę wysuniętą przez Longina i Solnika, iż dalsze badania powinny skupiać się na czynnikach fundamentalnych, które powodują wzajemne powiązania na rynkach światowych. Ponadto należy zwrócić uwagę na cykle gospodarcze, które obecnie mają tendencję do nakładania się na siebie, co przyczynia się do jednostronnych ruchów na rynkach finansowych całego świata [Longin, Solnik 1995, s. 26]. Pomagają temu przede wszystkim nowe systemy informacyjne, które pozwalają na niemal natychmiastowe reakcje inwestorów. Poza tym, jak można zauważyć na podstawie otrzymanych wyników badań korelacyjnych, silniejsze powiązania pomiędzy rynkami występują w krótszych okresach. Z kolei biorąc pod uwagę cały zakres badania (lata 1999-2011), można wyraźnie zauważyć, że trendy na różnych rynkach są od siebie zależne, ale częściej występują samodzielne wahania uzależnione od sytuacji wewnętrznej w danym kraju. Z kolei analizując polski rynek giełdowy reprezentowany przez indeks WIG, należy mieć na uwadze wzrost zależności z rozwiniętymi rynkami oraz ich ograniczenie z krajami rozwijającymi się. Może to być inspiracja do zbadania stopnia dojrzałości rynku polskiego, ponieważ na podstawie wyników można pokusić się o postawienie tezy, iż w chwili obecnej w zakresie stopnia rozwoju bliżej Polsce do USA oraz Niemiec, co niewątpliwie powinno nobilitować nasz kraj w zestawieniu atrakcyjnych rynków wartych zainteresowania inwestorów. 


\section{Literatura}

Danthine J.P., Giavazzi F., Thadden E.L., European financial markets after EMU: a first assessment, CEPR, 2000.

Forbes K., Rigobon R., No contagion, only interpedence: Measuring Stock Market Comovements, The Journal of Finance, X 2002, Tom LVII, numer 5, s. 2223-2261.

Horobet A., Searching for causes of the current financial crisis: on risk underassessment and ignorance, Review of Economic and Business Studies, VI 2010, s. 195-200.

Huber J., Rieger A., The EMU and Changes in Optimal Diversification Strategies in Europe: the Importance of Industry vs Country Effects, Department of Finance, University of Innsbruck, 2004.

Longin F., Solnik B., Is the correlation in international equity returns constant: (1960-1990), Journal of International Money and Finance, 1995, numer 14, s. 3-26.

Markwat T., Kole E., van Dijk D., Contagion as a domino effect in financial markets, Journal of Banking \& Finance, 2009, Tom 33, numer 11, s. 1996-2012.

Mink M., Mierau J., Measuring stock market contagion with an application to the sub-prime crisis, Working Paper DNB, VII 2009, numer 217/2009.

Syllignakis M., EMU's Impact on the correlation across the European stock markets, International Research Journal of Finance and Economics, nr 6/2006.

\section{CORRELATION ON THE GLOBAL FINANCIAL MARKETS}

Summary: The main objective of the paper was to study connections between the financial markets including the Polish stock exchange market. The author wanted to respond to the following questions:

- How strong are correlations among the main stock exchanges in the world?

- What is the time (bear market or bull market) with stronger interdependencies among global financial markets?

- What markets are most related to Polish WIG 20 Index?

The author gathered data from 1999 till 2011. Correlation is calculated for the main global stock exchanges but it also contains Polish market. We can see that the longer period of calculation the weaker connections among stocks all over the world. Furthermore in crisis time interdependencies are stronger what leads us to support a hypothesis that diversification among stock markets does not work properly because of global economy. Next research in this area should focus on the fundamental determinants of international correlation across equity markets. Studies have to take into consideration industry specifications of each national market as well as the correlation of the countries' business cycles.

Keywords: correlation, stock market, financial crisis. 